\title{
Gravity model and Pakistan - China Trade
}

\author{
Alexander Okhotnikov ${ }^{1}$, Muhammad Imtiaz Subhani ${ }^{3}$, Shatila Khodor $^{3}$, and Denis \\ Ushakov ${ }^{4}{ }^{*}$ \\ ${ }^{1}$ Rostov State Transport University, Rostov-on-Don, Russia \\ ${ }^{2}$ ILMA University, Karachi, Pakistan \\ ${ }^{3}$ IProCares Research Center, Beirut, Lebanon \\ ${ }^{4}$ Suan Sunandha Rajabhat University, Bangkok, Thailand
}

\begin{abstract}
Pakistan being an important ally of the war against terror paying huge price of not merely of innocent lives of people but huge monetary losses in many sectors of economy, one lucrative sector is international trade. Pakistan's export potential has undergone strenuous pressures to perform according to the past performance. There was a need to reveal new export potential and lucrative sectors of economy with recommended policy changes so that new paradigm change in international trade can be initiated. This empirical study carried to meet the objective in which gravity model is used for investigating the bilateral trade between Pakistan and China. This model is being used extensively by the researchers worldwide to make predictions about volume of international trade to suggest the policy changes in international trade management. The findings confirm that the tariff rates significantly and negatively affects the Export Volume from Pakistan to China as t-stats $>1.5$ which results the trade deficit to be increased, while the affinity (i.e. bilateral visits of people of Pakistan and China to each other countries, bilateral dialogues between China and Pakistan, Social integrations programs between China and Pakistan etc.) between China and Pakistan and Geography (i.e. the trading countries are both in Asia with the connected borders) significantly and positively affects the Export Volume from Pakistan to China as t-stats > 1.5 , thus the trade deficit is reduced due to stated affinity and geography. The large value of F-stats also reports that the relationships of export volume from Pakistan to China with all outlined stated explanatory variables/ predictors (i.e. the gravity model for bilateral trade between Pakistan and China) will remain alive for longer period of time in future.
\end{abstract}

\section{Introduction}

The area of research for this thesis focuses on empirically studying the effect of Afghan war on Pakistan's Export. The price Pakistan paying on war against terror is multifaceted from huge loss of innocent lives to billions of dollars yearly in economic losses; the major portion of this is export of Pakistan. The study has significance in academics as well as in policy making to improve the international trade and significantly reduce the current account deficit. Pakistan is suffering from huge current account deficit and balance of

*Corresponding author: denis.us@ssru.ac.th 
payment crisis, also been suffering from exchange rate instability and huge inflation in the face of $5.1 \%$ fiscal deficit. The study has explored the possible association between affinity and export volume and association between geographical proximity and export volume.

After 9/11 the scenario of the international trade changed a lot. United States of America entered in the Afghanistan in 2003 for eliminating the possibilities of any future incidents like 9/11. Pakistan being ally of US in this war, playing a vital role, to safeguard the interests of international community though Pakistan is paying an insurmountable price. After 9/11 the attitudes of international community towards exports of Pakistan changed. A study was required to measure the implications of changed attitudes and new economic geography this study was carried out to explore new export potential of Pakistan and redefine the lucrative sectors of economy.

In this background, it is important to enhance the volume of Pakistan's export potential at global level in general and regional level in particular. These potentials may be unexploited and this study may provide various policy implications to extend the export openings in a range of sectors and the countries where the potential opportunities exist. Hence, this study plans to apply gravity model analysis for this purpose. Extensively, the Gravity model has been used during the last forty years, because of the pioneering work of [1] in explaining bilateral and multilateral trade flows. In particular, this model has been used to solve various trade puzzles like finding of trade potentials, trade patterns, and estimation of the cost of border and for identification of effects related to regionalism [2].

This study is preponderantly concerned with finding of the untapped Pakistan's exports potential in these non-traditional markets (bordering Pakistan) such as India and China and nontraditional sectors of these economies. Broadly, the study investigates the following three questions (for the year 2003-2008).

1. Pakistan's aggregate export potential level with some selected trading partners at the global level.

2. Pakistan's export potential in various sectors of the Indian economy.

3. Pakistani exports in the Chinese market in different sectors.

This study analyzes export potential of Pakistan with countries with respect to geographical proximity and level of Affinity and identifies sectors and markets where Pakistan could focus on to improve its trade deficit and balance of payments.

The study sets forth following important objectives:

It estimates association between affinity and export volume between Pakistan and China.

It estimates association between geographical proximity and export volume between Pakistan and China.

It highlights sectors which Pakistan could focus on to increase its export volume.

It highlights markets which Pakistan could focus on to increase its export volume.

\section{Literature Review}

Laureate(Nobel Prize) is awarded of year 2008 on research in international trade and economic geography to US economist Paul Krugman, having shown the effects of the economies of scale on trade patterns and on the location of the economic activity, these ideas have given rise to an extensive reorientation of the research on these issues. Following is the findings of research on international trade that can strengthen the objectives of research carried out in this thesis [3].

The topic of "Pakistan China Free Trade Agreement on Trade Deficient" is based on the framework of gravity model on bilateral trade. The word Gravity model on bilateral trade has different meaning combined with each other as one word. When we a topic about 
gravity model on bilateral trade are discussed it mainly consists of two different concepts with one idea that is gravity and other is trade.

$[1,4]$ introduced the concept of econometric studies of trade flow based on the gravity equation. Their theory was based on international trade flow. According to his concept of Newton Gravitational law bring the idea of measuring countries trade flow. Through his work he had tried to explain the bilateral trade flow was between countries which have relation depending on economic size \& distance between those countries [5]. Firstly, a general model for export was specified and was bring into knowledge than many other economists came up with different new theories and invention in bilateral trade on gravity model.

When gravity model is considered, we take the idea of Newton example of apple falling from tree on the floor which he examined was due to some force which he names as gravity. On the other hand, when bilateral trade is being discussed the term is considered as trade between pair of countries in order to sort out the influence of geographical, cultural, preferential trading policies in creating concentration in trade.

According to [6] the gravity model since 1940 has a wide range of goods and factor of production and service moving from one place to another on level of regional and national boundaries under different circumstance. [7] named the model as fact of life.

In simple words cities, countries and region or other things that have higher number of people and are close together with similar choices are more likely to attract.

The gravity model is based on Newton Philosophy i.e. law of attraction and is drive from physic theory, which explain the concept that a flow is connected as the result of attraction between two objects. In some cases, gravity model is an analysis with international trade flow which is known as FDI. Foreign direct investment is concerned with international direct investment depending on long term relationship \& beneficial influence on the firm management in a particular country.

$[8,9,10,11]$ reported gravity equation as a consumer expenses or expenditure equation with the prices in order to use general equilibrium constraint concept as an important element. [12] reported the theory by adding more variable to the theory and justify general equilibrium system.

[13] investigated that the same gravity equation can come in various setting including or excluding hetegeneous firms.

[14] explain a modern version of gravity equation of trade driven by Ricardian comparative advantage.The main objective of developing a working system for analyzing international trade flow based on bilateral trade volume for department of trade and industry. As per the researcher the traditional gravity model objective contains following three elements.

Economically effecting the trade flow in the exporting country

Economically effecting the trade flow in the importing country

Natural factor enhancing and effecting trade flow between trading partners.

The major variable of gravity equation are GNP and GDP of two countries their population and the distance between them. It is based on economic sizes (often using GDP measurement). The theory explain that trade is measured on gross sale basis while considering GDP is measured on value added basis. $[15,16,17]$ also explain GDP concept. When we talk about GNP \& GDP it focusses on demand and supply side effecting trade.

As per Isaac Newton's theory it represents a reduction which comprises of supply and demand element (GDP or GNP) population as well as geographical distance such as transport cost and other trade factor.

[15] investigated GDP as price affection is also captured through real exchange rates.

Other researcher like [18] investigated different and new theories and concept of gravity model to justify the trade theories. 
It is one of the popular equation successfully used in reference with international economic.

[19] reported gravity equation has gone through the process of embarrassment of poverty to embarrassment of riches.

[20] reported the model as "workhorse". Workhorse model was used in 2000.It is named as workhorse as it international trading ability correctly approximate bilateral trade flow making a stable relationship in economics.

Nowadays the concept of gravity model on bilateral trade has become popular and one of the hottest fashion trend according to many researchers. When the trade volume increases the product economic size and decreases the physical geographical distance. It became great success stories between among economist.

[21] name the model as Border related cost that take place between two countries on the basis of similar choices or some common interest.

$[22,23]$ define the concept in detail by calculating each country total import and export which divides the determinants of international trade into two categories. One is the factors which influence the level of total import and export of the countries around the world, and second is geographical distribution.

[24] reported by doing a survey and identified two approaches for bilateral trade.

[9] investigated gravity model as a foundation of micro economic frame work highlighting general equilibrium model. According to him consumer is having maximum CES preferences \& profit maximizing function (CET) as production technology. His concept explains a link between a production of import and export supply equation which is combined with equilibrium condition that lead a reduction from equilibrium quantities (export /import) and prices.

According to $[25,26]$ explain the concept as the countries which are developed have un natural trading partner because of their alike comparative advantages, endowment and limited economic size and higher trade cost.

[27] was first to introduce the dis aggregated data on the prediction with the volume of export which is proportional with the volume of export which is connected to GDP only in those countries where there is no barrier to entry.

[28] reported gravity model analysis are used to evaluate various trade policy issues such as the effect of protection.

During 1970-90 [29] used bilateral trade concept for a panel of 186 countries for finding small but statistically significant exchange rate.

The concept is based on two major elements.

Firstly, the transportation cost is counted.

Second the collinearity emerging if we use distance twice.

There is nothing new about trade but what creates bilateral trade is the idea of trade between two countries on some interest among countries like US and Canada, Pakistan \& China really matter.

For many research the definition has been given by comparing currency union which is named as cooperate arrangement. In this process countries freeze their exchange rates at a constant rate to reduce the uncertainty linked with volatile exchange rate.

The result of gravity model reveals the product of two countries where GDP has positive and significant impact on bilateral trade in fact 1\% GDP lead to it. Researcher has reported to concept of gravity model with trade that is the reason for countries to enter world trade but trade flow is unknown second gravity model used to analyze pattern and performance of international trade where quantity of trade flow is examined.

Bilateral trade is more clearly negotiated than multilateral trade because they involve only two countries. When negotiations for a multilateral trade do not work out, many of the nation's bilateral trade instead take place. However, bilateral trade often triggers competing 
challenge between other countries. This can take away the advantages the Free Trade (FTA) confers between the pristine two nations.

In 1950 and 1960 bilateral trade between japan and United States was created. Where as in 2000 till 2010 bilateral trade activities between Vietnam and 60 countries took place.

Whereas [30] reported total income determine the level of demand in importing country and level of supply in exporting country.

[31] research the gravity model of trade flow is examined by valued which is obtained under market equilibrium condition where supply for demand and supply for trade flow are equal.

Some study by researcher reported gravity model is the effect of real exchange rate with the uncertain condition of bilateral trade flow. There is various example of bilateral trade agreement represented by researcher like Pakistan \& China, Brazil \& México, Latin America \& Australia. If we talk about gravity model with connection with bilateral trade it includes trading concept import and export. Pakistan has highest trade potential with different countries like Norway, China, Greece, Bangladesh etc.

Here bilateral trade is connected with trade with different countries especially china and Pakistan. Gravity model on bilateral trade has a closer connection of trade between Pakistan and china. Pakistan has always faced the problem of import than export.

Gravity model is a combination of volume of trade, capital flow and migration among the countries of the world. Economic size and geographical distance 2 main element in bilateral trade.

If talking about implementing bilateral trade in Pakistan, the gravity model finds trade potential of Pakistan with its border sharing and other trading partners. Pakistan is trading with more than 175 countries. It is important to enhance the volume of Pakistan export at global and regional plat form. In this regard gravity model on bilateral trade place an important role. Trade between Pakistan and China has always been very beneficial as their interest are same and lead toward successful bilateral trade.

China Pakistan free trade agreement (FTA) was introduced in 2007 which was a new experiment to boost bilateral trade. Many factor are involved in the growth of Pakistan economic relation with china. Some of them are mentioned as under.

Poor innovation and technology infra structure.

Increased cost of export in terms of export.

Low labor productivity

Anti-export bias in taxation

Pakistan and China have long bounding relationship. They have developed strong trading relation as Pakistan has always being poor with their economy system and to have successful growth in business and economy Pakistan always need strong support like financially and china has always been there. The relation starts since 1951 and is growing with various investment of china in several Pakistani projects. According to latest research in 2015 the bilateral trade between both countries had reached the \% up to $\$ 9.3$ billion. Large number of Chinese companies are operative in Pakistan.

\section{Research Methodology}

This study is exploratory and analytical in nature. It takes into account quantitative data of Pakistan and China for the period 2004-2016. These 2 countries (Pakistan and China) are selected in the sample because Pakistan's exports/imports to/ from china are significant. Which can be seen in the following table, where the export data for top 20 export markets for Pakistan is provided for the period 2004-2016 where the export volume with china is found at the rank number three. 
Further in developing the econometrical methodology to investigate the main proposition of this research which is the investigation of trade between the china and Pakistan while using the gravity model and keeping in view the china Pakistan trade agreement in the context of economic corridor, the three independent variables are Tariff, Affinity and Geography are taken. It should be noted that for Tariff, its percentage value is taken as it was taken as the quantitative variable, while variables Affinity and Geography are introduced as dummy variables in the model opted and used in this research.

Since two dummy variables are used, to estimate the slope of these variables separately, two more variables are introduced in the model as a combination of tariff and affinity and tariff and geography $[32,33]$.

Multiple regression model is used to estimate the coefficient and R-square for the model to address the bilateral trade between the china and Pakistan while using the gravity model and keeping in view the China Pakistan trade agreement in the context of economic corridor $[34,35]$.

Table 1. International Trade of Pakistan, 2004-2016.

\begin{tabular}{|c|c|c|c|c|c|}
\hline & Countries & $\begin{array}{c}2004-2008 \\
\%\end{array}$ & $\begin{array}{c}2008-2012 \\
\%\end{array}$ & $\begin{array}{l}\text { 2012-16, } \\
000 \text { USD }\end{array}$ & $\begin{array}{c}2012-2016 \\
\%\end{array}$ \\
\hline 1 & USA & $31.25 \%$ & $30.70 \%$ & $3,719,360$ & $24.59 \%$ \\
\hline 2 & UAE. & $9.78 \%$ & $10.16 \%$ & $2,070,953$ & $13.69 \%$ \\
\hline 3 & CHINA & $8.52 \%$ & $9.02 \%$ & $1,206,436$ & $7.98 \%$ \\
\hline 4 & AFGHANISTAN & $7.93 \%$ & $5.53 \%$ & $1,143,663$ & $7.56 \%$ \\
\hline 5 & UK & $6.67 \%$ & $6.97 \%$ & $1,030,028$ & $6.81 \%$ \\
\hline 6 & GERMANY & $5.12 \%$ & $5.15 \%$ & 816,615 & $5.40 \%$ \\
\hline 7 & ITALY & $4.36 \%$ & $4.69 \%$ & 723,631 & $4.78 \%$ \\
\hline 8 & SPAIN & $3.10 \%$ & $3.42 \%$ & 542,099 & $3.58 \%$ \\
\hline 9 & NETHERLANDS & $2.97 \%$ & $3.24 \%$ & 514,859 & $3.40 \%$ \\
\hline 10 & TURKEY & $2.27 \%$ & $2.86 \%$ & 435,981 & $2.88 \%$ \\
\hline 11 & BELGIUM & $2.40 \%$ & $2.64 \%$ & 409,431 & $2.71 \%$ \\
\hline 12 & SAUDI ARABIA & $2.45 \%$ & $2.12 \%$ & 380,080 & $2.51 \%$ \\
\hline 13 & FRANCE & $2.51 \%$ & $2.54 \%$ & 365,809 & $2.42 \%$ \\
\hline 14 & BANGLADESH & $2.00 \%$ & $1.92 \%$ & 341,958 & $2.26 \%$ \\
\hline 15 & SOUTH AFRICA & $1.94 \%$ & $2.06 \%$ & 318,461 & $2.11 \%$ \\
\hline 16 & INDIA & $2.19 \%$ & $2.52 \%$ & 254,858 & $1.68 \%$ \\
\hline 17 & OMAN & $0.52 \%$ & $0.47 \%$ & 223,748 & $1.48 \%$ \\
\hline 18 & SRI LANKA & $1.19 \%$ & $1.47 \%$ & 214,582 & $1.42 \%$ \\
\hline 19 & IRAN & $1.40 \%$ & $1.23 \%$ & 213,800 & $1.41 \%$ \\
\hline 20 & SOUTH KOREA & $1.43 \%$ & $1.28 \%$ & 200,045 & $1.32 \%$ \\
\hline & TOTAL & & & $15,126,397$ & \\
\hline
\end{tabular}

\section{Findings and Results}

In the model, we have 6 variables, one dependent and 5 independent/explanatory variables or regressors.

$\mathrm{Yi}=\mathrm{B} 1+\mathrm{B} 2 \mathrm{X} 2 \mathrm{i}+\mathrm{B} 3 \mathrm{X} 3 \mathrm{i}+\mathrm{B} 4 \mathrm{X} 4 \mathrm{i}+\mathrm{B} 5 \mathrm{X} 5 \mathrm{i}+\mathrm{B} 6 \mathrm{X} 6 \mathrm{i}+$ Error Term

Where

$\mathrm{Yi}=$ Mean Export Volume to Country i,ORExport Volume from Pakistan to China

$\mathrm{X} 2 \mathrm{i}=$ Average Tariff Rates in the importing country

$\mathrm{X} 3 \mathrm{i}=1$ if there is high affinity between trading countries and 0 Otherwise

$\mathrm{X} 4 \mathrm{i}=1$ if the trading countries are both in Asia with the connected borders and 0

Otherwise 
$\mathrm{X} 5 \mathrm{i}=\mathrm{X} 2 \times \mathrm{X} 3$, If $\mathrm{X} 3=1$, then $\mathrm{X} 5 \mathrm{i}=\mathrm{X} 2 \times \mathrm{X} 3$ and if $\mathrm{X} 3=0$, then $\mathrm{X} 5 \mathrm{i}=0$

$\mathrm{X} 6 \mathrm{i}=\mathrm{X} 2 \times \mathrm{X} 4$, If X4 $=1$, then X6i $=\mathrm{X} 2 \times \mathrm{X} 4$ and if $\mathrm{X} 4=0$, then X6i $=0$

The findings confirm that the tariff rates and its increase will lead to a decrease in Export Volume from Pakistan to China as t-stats $>1.5$, it should also be noted that the corresponding beta in negative (-156206.800) shows that, a single unit increase in tariff rate will lead to a reduction is export volume from Pakistan to China to 156206.8 units [34], hence the trade deficit of Pakistan is increased, which implies that between the china and Pakistan there should not be any trade protectionism like tariffs etc.

The findings of coefficients table further report that affinity (i.e. bilateral visits of people of Pakistan and China to each other countries, bilateral dialogues between china and Pakistan, Social integrations programs between china and Pakistan etc.) between China and Pakistan also a key player of the trade between these two nations as the affinity between these two nations significantly effects positively to Export Volume from Pakistan to China as the corresponding t-stats $>1.5$.. Further the single unit increase in stated affinity leads to an increase of 111358.265 units of exports from Pakistan to China and hence the trade deficit of Pakistan is reduced.

The coefficients table further reports that Geography (i.e. the trading countries are both in Asia with the connected borders) also significantly and positively affects the Export Volume from Pakistan to China as t-stats $>1.5$. Moreover, the one unit increase in such stated affinity leads to an increase of exports from Pakistan to China by 56564.545 units; hence the trade deficit of Pakistan is reduced.

The table of model summary confirms that the deployed model is sufficiently strong as adjusted R- square is .387 , and reliable and significant as F-stats is 818.450 which is more than 3.84. The large value of F-stats i.e. 818.450 also reports that the relations ships of export volume from Pakistan to China with all outlined stated explanatory variables/ predictors (i.e. the gravity model for bilateral trade between Pakistan and China) will remain alive for longer period of time in future.

\section{References}

1. J. Timbergen, Shaping the World Economy: Suggestions for an International Economic Policy (Twentieth Century Fund. Jan Timbergen, New York, 1962)

2. W. Butt, Pakistan's Export Potential: A Gravity Model Analysis (Editor, SBP, 2009)

3. P. Krugman, Geography and Trade (MIT Press, Cambridge, 2000)

4. P. Poyhonen, Wetwirtschaftliches Archiv 90 (1963)

5. E.G. Popkova et al. European Research Studies Journal 20(1) (2017)

6. V. Oguledo, C. Macphee, Applied Economics 26 (1994)

7. A. Deardorff, Determinants of Bilateral Trade: Does Gravity Work in a Neoclassical World?' (Regionalization of the World Economy, 1998)

8. J. Anderson, American Economic Review 14 (1979)

9. J. Bergstrand, The Review of Economics and Statistics 71(1) (1989)

10. D.I. Stepanova et al., International Journal of Economics \& Business Administration 7(1) (2019)

11. D. Ushakov et al., Montenegrin Journal of Economics 13(1) (2017)

12. H. Linnemann, An Econometric Study of International Trade Flows (Amsterdam, North Holland, 2002)

13. C. Arkolakis et al., American Economic Review 16 (2016) 
14. J. Eaton, et al., International Trade: Linking Micro and Macro (University of Chicago, Mimeo, 2010)

15. J. Brun et al., World Bank Economic Review 19(1) (2005)

16. Z. Jakab et al., Journal of Comparative Economics 29 (2001)

17. H. Kościelniak et al., Polish Journal of Management Studies 16(1) (2017)

18. A. Deardorff, Determinants of Bilateral Trade: Does Gravity Work in a Classical World? (University of Chicago Press, Chicago, 1998)

19. J. Frakel, Regional Trading Blocs in the World Economic System (Institute of International Economics. Washington D.C., 1997)

20. B. Eichengreen, D. Irwin, The Role of History in Bilateral Trade Flows (University of Chicago Press, Chicago, 1998)

21. L. Fontagne et al., CEPII Working Paper 04 (2004)

22. K. Kunimoto, Hitotsubashi Journal of Economics 17 (1977)

23. T. Vollrath, A Weltwrits chaftliches Archive 130 (1991)

24. P. Drysdale, R. Garnaut, Hitotsubashi Journal of Economics 22 (1982)

25. P. Krugman, American Economic 70 (1980)

26. C. Magee, Contributions to Economic Analysis and Policy 2(1) (2003)

27. T. Podolskaya et al., E3S Web of Conferences 244 (2021)

28. J. Wall, Using the Gravity Model to Estimate the Costs of Protection (Federal Bank of Saint Louis, 1999)

29. A. Rose, E. Wincoop, National Money as a Barrier to International Trade: The Real Case for Currency Union (Fedral Reserve Bank of New York, 2001)

30. V. Oguledo, C. Macphee, Applied Economics 26 (1994)

31. D. Karemera, et al., Journal of Economic Integration 14(3) (1999)

32. Gujarati: Basic Econometrics (The Mc-Graw Hill Companies, 2004)

33. M. Ihnatenko et al., International Journal of Economics and Business Administration 7(2) (2019)

34. O. Zakharchenko et al., Journal of Reviews on Global Economics 8 (2019)

35. A. Př́vara, M. Př́ivarová, Sustainability 11(20) (2019) 